Available online at: https://journals.researchsynergypress.com/index.php/ijtaese

International Journal of Theory and Application in Elementary and Secondary School Education

(IJTAESE)

ISSN 2684-7167 (online)

Volume 3 Number 2 (2021): 01-06

\title{
Contribution of Writing Interest toward Indonesian Language Learning of Students in Vocational High Schools
}

\author{
Faizal Arvianto
}

Timor University, Indonesia

\begin{abstract}
This research aims to find out how the contribution of writing interest toward Indonesian language learning of students in vocational high schools in the city of Kefamenanu, East Nusa Tenggara province. This study utilised a quantitative method with a correlational approach. Based on the results of data analysis, data on student writing interest was in averaged $74.8 \%$ with good category. Based on the calculation results, there was a correlation of about 0.290 and was included correlation coefficient in the low category. The result of the significance t-test shows that $t$ count score was 3.248 . Referring to the results of the study, it can be concluded that there is a positive and significant correlation between the writing interest toward Indonesian language learning of the students of grade X of vocational high schools in Kefamenanu.
\end{abstract}

Keywords: contribution, writing interest, Indonesian language learning.

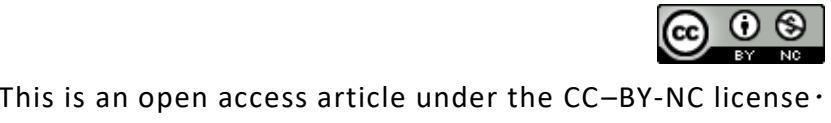

\section{INTRODUCTION}

Indonesian language learning has four components of language skills that must be mastered by students. These four components exist in every Indonesian language learning competency standard. According to Tarigan (2008: 1), the four components are listening skills, speaking skills, reading skills, and writing skills. Each of these skills has a close relationship with each other. As stated by Dawson (in Tarigan, 2008: 1) that the four language skills are basically a single-chess that is interrelated.

Language skills can be mastered by doing a lot of practice and mastering several concepts. If you do not practice, these language skills will not be improved. Speaking well means mastering all of the language skills. There are two language skills that we know, productive and receptive. Productive skills are the skills of creating and presenting languages, while receptive skills are skills of accepting and interpreting languages.

Writing skill is one of the fundamental language skills in Indonesian language learning that requires students to be able to master the rules and elements related to writing activities such as language structure, vocabulary, and writing. Not only in structure, but students are also expected to be able to make solid sentences and relate them to become complete sentences. This certainly requires students to continue to learn and practice writing skills.

Referring to the results of an interview with an Indonesian teacher of a vocational school in the city of Kefamenanu East Nusa Tenggara province, it was found that the results of writing produced by students when compiling papers and making papers in Indonesian language learning turned out to be inadequate.

Corresponding author

Faizal Arvianto, faizal_arvianto@unimor.ac.id

DOI: https://doi.org/10.31098/ijtaese.v3i2.499

Research Synergy Foundation 
This can be seen when students still have difficulties in (a) choosing and arranging ideas with logical and systematic thoughts, (b) pouring their ideas into Indonesian language speech in accordance with Indonesian language rules, (c) Producing effective writing in accordance with general guidelines of Indonesian spelling; and (d) choosing a variety of Indonesian languages in accordance with the context needed.

Based on the above issues, the students' low interest in writing is considered to be one of the causes of the lack of significant results of students writing when composing papers in Indonesian language learning. The same to (in Siagian, 2012: 125) explains that interest is a fixed tendency to pay attention to and remember some activities. Activities that appeal to students will be continuously and conveniently considered and carried out. Furthermore, Slameto also stated that interest is a feeling of liking and interest in a matter or activity without being told. When someone realises that writing is a valuable activity, he will carry it out with pleasure. In line with this, Chlarson (2011: 52), in his research, stated that with a high interest in writing, a student would produce more qualified writing. Conversely, when students have a low interest in writing, the results of their writing are less with lower quality.

Interest, according to Ambarjaya (2012: 20), means a tendency and high enthusiasm or a great desire for something. Interest can affect the quality of students learning outcomes in accordance with certain fields of study. This means interest is the core capital for someone to achieve something. In writing skills, students must have the interest to be willing to write. As stated by Romli (2009: 33), being a writer cannot be forced, but there must be encouragement from within for self-awareness and willingness. Interest can encourage students' enthusiasm and tenacity to write.

Due to these problems and gaps, the researcher is interested in examining whether or not there is a contribution of the variable of students' interest in writing towards Indonesian learning. Thus, the researcher finally conducted research with the title "Contribution of Writing Interest toward Indonesian Language Learning of Students of Vocational High Schools."

\section{LITERATURE REVIEW}

Learning

According to Hamalik (2013: 2), learning is a form of intertwined activities in the teaching and learning process between teachers and students to develop the behavior in achieving the educational goals. Furthermore, Arifin (2012:12) said that learning is a process or manner which is done by someone to do learning activities. Based on the expert's opinions above, it can be synthesized that learning is a process of interaction between students and their environment, which creating learning activities, so an alteration for their better experience and behavior happened.

\section{Writing Interest}

Interest, according to Ambarjaya (2012: 20), means a tendency and high enthusiasm or a great passion toward something. So far, interest as known and used by people can influence the quality of students learning achievement in certain fields of study. Chaplin (in Arvianto, 2018: 11) formulated interest in three kinds. First, as a persistent attitude binding individual attention towards certain objects selectively, second, as an individual, meaningful feeling about the activities, odd jobs, or objects faced by each individual, and the last, as the readiness of individual who manage or control the behavior in a particular direction or towards certain goals. Interest is psychological phenomenon that encourage someone to do something or give full attention to a particular object so that someone can do the work happily and continuously. 
Writing is depicting graphic symbols that reflect a language understood by someone, so other people can read the symbols of the graph (Tarigan, 2008: 22). Based on the definition of interest and writing, it can be synthesized that interest in writing is an interest or a great desire for the activity of conveying messages through written media. In other words, interest in writing is a great desire with awareness, willingness, attention, and feelings, along with a great passion for carrying out writing activities because of the encouragement and tendencies to be obtained from the writing activity.

\section{Indonesian Language Learning}

In general view, learning is often defined as an activity or effort to gain knowledge. Learning is behavior alteration as a result of experience (Imron, 1996: 15). Learning is also a deliberate process that is done consciously. Based on this view, learning can be defined as an activity or human conscious effort to gain knowledge that changes behavior.

Furthermore, learning can be interpreted as efforts that are made so the learning process can occur. Learning is intended to create an atmosphere or conditions, so students are able to learn (Imron, 1996: 43). From this explanation, it can be seen that learn and learning are activities where teachers and learners interact. From the interaction that occurs between the teacher and students, then the term teachinglearning process emerges.

According to Usman (2005: 4), the teaching-learning process is a process that contains a series of activities of teachers and students on the basis of reciprocal relationships that take place in educational situations to achieve certain goals. From these theories, it can be concluded that teachers and students are two crucial components in learning. Imron (1996: 46) revealed that the dynamic elements of learning included the following: (1) motivation and efforts to encourage students to learn, (2) learning materials and efforts to provide them, (3) learning kit and efforts to provide them, (4) the atmosphere of learning and its development efforts, and (5) the learning subject condition and efforts to prepare and fulfill them. The dynamic elements of learning expressed by Imron above are elements that must be involved in every learning process. Besides dynamic elements of learning, several things that are directly related to learning include learning objectives, learning materials, learning methods, learning media, and learning evaluation.

According to Muslich (2010: 127) Indonesian language learning in Indonesia basically has the double task, as a tool of national education and as a medium for fostering the Indonesian language. Indonesian as a national education tool is directed to guide students in the learning process so students can have valid knowledge of the Indonesian language; so students can be skilled in using the Indonesian language both in speaking or in understanding speech; have a positive mental attitude towards Indonesian. Indonesian language learning is not only dealing with students' problems in learning Indonesian but also deals with the complexity of the Indonesian language itself.

Based on the views of these experts, Indonesian language learning can be synthesized as the activities of teaching and learning Indonesian language materials carried out consciously by teachers and students on the basis of reciprocal relationships that occurred in educational situations to achieve certain goals.

\section{RESEARCH METHOD}

The research method used by the researcher in this study was a quantitative method with a correlational approach, namely an approach that focuses on interpreting covariations among naturally occurring variables (Emzir, 2011: 37). This study aims at identifying the contribution of the variable of 
writing interest towards Indonesian language learning of grade X students of Vocational Schools in Kefamenanu City by testing data based on correlation technique.

The flow of research related to research was carried out as follows: a) identification of problems in Vocational Schools in Kefamenanu City, the results of which were formulated in the formulation of the problem, b) gathering theories that are in line with the problems of experts related to this research variable. These theories play a role as a support for the research that the researcher carried out, c) collection of data and documentation needed. The data were the student's interest in writing and in the process of Indonesian language learning, d) data analysis was related to students interest in writing in Indonesian learning, e) the results of data analysis were described by researchers who were supported by statistical test formulas related to the research, $\mathrm{f}$ ) the final stage was verification, the researcher drew the conclusion related to the results of the analysis carried out previously.

The population of this study was the tenth-grade students of Vocational High Schools (SMK) in Kefamenanu City, and one school was selected as a sample with 117 students. Data collection techniques used by researchers in this study are as follows.

a. Observation

The observation was done by looking directly at the condition of the research location.

b. Questionnaire

The questionnaire was data collection techniques carried out by giving a set of questions or written statements to respondents to measure student's interest in writing. The questionnaire uses Likert scale form, namely the measurement scale used to measure attitudes, opinions, and perceptions of a person or group of people about social phenomena (Sugiyono, 2016: 93). This questionnaire demanded a number of statements consisting of positive statements and negative statements. Each item was divided into four scales, which were very appropriate, appropriate, inappropriate, and very inappropriate.

Data analysis was done by using tables and using correlation test techniques Product Moment Correlation and Relative Frequency Distribution. Then, the data were presented descriptively by describing the results of data processing. Questionnaire data were processed using Relative Frequency Distribution. Then, scores and categories were carried out on each student's answer, as in table 1.

Table 1. Mark Classification

\begin{tabular}{ll}
\hline Mark Percentage (\%) & Categories \\
\hline $\mathbf{0 0 - 2 0}$ & Very Lack \\
$\mathbf{2 1 - 4 0}$ & Lack \\
$\mathbf{4 1 - 6 0}$ & Adequate \\
$\mathbf{6 1 - 8 0}$ & Good \\
$\mathbf{8 1 - 1 0 0}$ & Very Good \\
\hline
\end{tabular}




\section{FINDINGS AND DISCUSSION}

The results of data analysis and hypothesis testing showed that alternative hypotheses were accepted. In testing the hypothesis, there was a positive and significant relationship between interest in writing and Indonesian learning. This means an increase in interest in writing was also followed by an increase in learning outcomes in Indonesian and vice versa.

The results of the analysis of interest in writing indicate that students attained the highest score of 116 and the lowest score of 77 out of a total of 33 statements on the student interest in writing skills. The average score obtained by students was 98.74 of the total score of 132 , so the level of student's interest in writing was $74.8 \%$ of the expected $100 \%$ and included in the good category.

Furthermore, $t$ table was obtained from the table of $r$ product moment values for a significant level of $5 \%$ with $n=117$, obtained by $t$ table of 0.195 (Sugiyono, 2016: 333). Based on the calculation results, it was found that the value of $t$ count was greater than the value of $t$ table, then the null hypothesis was rejected, and the alternative was accepted. Based on these calculations, it was obtained a correlation of 0.290 which based on the classification of correlation coefficients included in the low and significant categories of 3.248. This shows that students' interest in writing is positively and significantly related to Indonesian learning.

As Ambarjaya (2012:20) has stated that interest is something that can affect the quality of student achievement in a particular field, it can be interpreted if the high or low results of student achievement in a field are determined by the high or low interest of students in the field. The connection with the results of this study, that interest can indeed determine the level of achievement of students in learning Indonesian at school.

\section{CONCLUSION}

In regard to the results of the research and testing of the hypotheses that have been discussed, the conclusion of this study is that there was a positive and significant relationship between interest in writing with Indonesian language learning in grade X of Vocational High Schools in Kefamenanu City. This shows that there was a positive contribution from the variable of writing interest towards Indonesian learning. If the interest in writing students is good, then learning Indonesian students will also reach good results.

The results of the research, discussion, and conclusion that have been presented lead the researcher to provide the suggestions as follows:

\section{Advice for Students}

a. Increase interest in writing skills because high interest will make students excited about practicing and learning things related to writing.

b. Familiarise yourself in writing activities and pay attention to the use of cohesion and coherence so that the writings could be well produced by students and relevant so that they could produce communicative and effective writing.

\section{Suggestions for Teachers}

a. Provide the motivation to students to increase their interest in writing skills.

b. Conduct writing activities with the use of interesting methods, techniques, and models, so students are interested in writing activities.

c. Provide training to students in writing skills, especially on students' mastery of cohesion and coherence. 


\section{Suggestions for Schools}

a. Carry out activities related to students writing skills so that students are more motivated to do writing activities.

b. Provide facilities and infrastructure related to student writing activities.

\section{Suggestions for other researchers}

a. Researchers could consider this research as a reference for the same type of research.

b. Researchers could deepen the results of this study by expanding the population and samples or the research variables.

\section{REFERENCES}

Ambarjaya, Beni. 2012. Psikologi Pendidikan \& Pengajaran. Yogyakarta: CAPS.

Arifin, Zainal. 2012. Evaluasi Pembelajaran. Jakarta: Direktoral Jenderal Pendidikan Islam Kementerian Agama RI.

Arvianto, Faizal. 2018. "Hubungan Antara Minat Menulis dengan Penguasaan Peranti Kohesi dan Koherensi dalam Pembelajaran Bahasa Indonesia pada Siswa Kelas X SMK Sekota Sukabumi Tahun Pelajaran 2016/2017". Metalingua. Vol. 16. No. 1. Hal: 7-15.

Charlson, Kelsey. 2011. "Effects of High-Interest Writing Prompts on Performance of Students with Learning Disabilities". Thesis. Utah: Utah State University.

Emzir. 2008. Metodologi Penelitian Pendidikan: Kuantitatif Dan Kualitatif. Jakarta: Raja Grafindo Persada.

Hamalik, Oemar. 2013. Kurikulum dan Pembelajaran. Jakarta: PT Bumi Aksara.

Imron, Ali. 1996. Belajar dan Pembelajaran. Jakarta: Dunia Pustaka Jaya.

Muslich, Mansur. 2010. Bahasa Indonesia Pada Era Globalisasi: Kedudukan, Fungsi, Pembinaan, dan Pengembangan. Jakarta: PT Bumi Aksara.

Romli, Asep M. Syamsul. 2005. Jurnalistik Praktik Untuk Pemula. Bandung: Remaja Rosdakarya.

Siagian, Roida Eva Flora. 2012. "Pengaruh Minat dan Kebiasaan Belajar Siswa terhadap Prestasi Belajar Matematika”. Jurnal Formatif. Vol. 2. Hal. 122-131.

Sugiyono. 2016. Metode Penelitian Kuantitatif, Kualitatif, dan R\&D. Bandung: Alfabeta.

Tarigan, Hendri Guntur. 2008. Menulis: sebagai suatu keterampilan berbahasa. Bandung: Angkasa Bandung.

Usman, Uzer. 2005. Menjadi Guru Profesional. Bandung: Remaja Rosdakarya. 